\title{
RANCANG BANGUN APLIKASI PREDIKSI PENJUALAN MENGGUNAKAN ALGORITMA DOUBLE EXPONENTIAL SMOOTHING BERBASIS WEB (STUDI KASUS: PT. SANPAK UNGGUL)
}

\author{
Richard John ${ }^{1 *}$, Seng Hansun ${ }^{1}$ \\ ${ }^{1}$ Program Studi Teknik Informatika, Universitas Multimedia Nusantara \\ Jl. Boulevard Gading Serpong, Scientia Garden, Tangerang \\ E-mail: John_inteligence123@yahoo.co.id,hansun@umn.ac.id \\ Korespondensi penulis
}

\begin{abstract}
Abstrak: Penelitian ini bertujuan untuk melakukan peramalan penjualan di masa mendatang beserta fiturfitur aplikasi lainnya seperti kemampuan untuk menambahkan (insert), mengubah (edit), dan menghapus (delete) data produk dan ringkasan penjualan yang akan atau telah disimpan dalam suatu database untuk studi kasus perusahaan tertentu. Aplikasi yang dibangun menggunakan algoritma double exponential smoothing. Alasan pemanfaatan algoritma ini adalah nilai smoothing akan diperoleh tepat waktu sebelum data aktual saat data historis memiliki komponen trend. Oleh karena itu, untuk nilai smoothing tunggal, perlu ditambahkan nilai dari double smoothing untuk menyesuaikan trend tersebut. Metode yang dapat digunakan untuk memprediksi trend linear adalah metode dua parameter Holt. Pada metode Holt, nilainya bukan trend halus dari double smoothing secara langsung, melainkan penghalusan trend dilakukan dengan menggunakan parameter yang berbeda dengan yang digunakan untuk menghaluskan data aslinya. Hasil penelitian menunjukkan bahwa aplikasi yang dibangun memiliki persentase kesalahan sekitar 28,38\%. Aplikasi yang dibangun juga mampu memenuhi fitur-fitur yang dikehendaki oleh user dalam pemrosesan produk dan rekapitulasi.
\end{abstract}

Kata kunci: Double exponential smoothing, aplikasi peramalan, prediksi penjualan, trends

\begin{abstract}
In this research, we aim to make predictions on sales in future periods as well as other application features such as insert, edit, and delete data products and sales summary that will be or have been stored in a specific database for a specific case study. The application built uses double exponential smoothing algorithm. The rationale of this method is that the value of smoothing will be found in time before the actual data when the data contained trend component. Therefore, for a single smoothing value, need to be added to the value of the double smoothing to adjust trend. The method that can be used to predict the linear trend is two-parameter method of Holt. At Holt method, the value is not smoothed trend with double smoothing directly, but the trend smoothing is done by using different parameters with the parameters used for smoothing the original data. The results showed that this application has a forecasting error percentage of $28.38 \%$. This application is also able to fulfill the features desired by the user in the process of product and recapitulation.
\end{abstract}

Keywords: Double exponential smoothing, forecast application, sales forecasting, trends.

\section{PENDAHULUAN}

Sebuah fakta bahwa waktu adalah uang dalam aktivitas penjualan. Pengambilan keputusan merupakan hal yang penting untuk kesuksesan penjualan. Dalam hal ini seseorang yang memiliki wewenang untuk mengambil keputusan akan membuat prediksi sebelum melakukan tindakan. Orang tersebut mungkin tidak sadar bahwa apa yang dilakukannya adalah membuat prediksi, namun pilihan yang dilakukan akan dipengaruhi oleh pengalaman dan pengetahuannya terhadap data-data di masa lalu.

Menurut Bambang Soepeno [1], data di masa lalu sulit untuk dianalisa karena acak dan penuh dengan ketidakpastian. Ketidakmampuan dan keterlambatan menganalisa data tersebut saat pengambilan keputusan akan mengakibatkan kegagalan. Oleh sebab itu, perlu suatu teknik perhitungan untuk membantu sang pengambil keputusan dalam menentukan langkah yang tepat agar penjualan tersebut dapat sukses dan efektif.

Salah satu cara yang tepat untuk mengatasi ketidakpastian dan membantu prediksi sang pengambil keputusan tersebut adalah dengan metode peramalan penjualan. Dengan menggunakan metode peramalan penjualan yang tepat, beberapa masalah seperti pengambilan keputusan dalam menambah atau mengurangi stok, pemberian diskon, tambah atau kurangi jenis produk yang dijual, dan lain-lain dapat diatasi dengan tepat. Pemilik perusahaan menjadi lebih mudah dalam melakukan proses pembelian dan pengadaan stok barang. 
Aplikasi ini berbasis web dan disusun menggunakan bahasa pemrograman PHP, sehingga tidak perlu melakukan instalasi aplikasi di tiap komputer yang membutuhkan. Aplikasi ini juga kompatibel pada komputer apapun selama terdapat web browser pada komputer tersebut. PT. Sanpak Unggul dipilih sebagai studi kasus dikarenakan penjualan pada perusahaan tersebut memiliki trend yang meningkat setiap tahunnya. Pola data trend akan cocok apabila diolah menggunakan algoritma Double Exponential Smoothing.

Penelitian tentang peramalan penjualan telah banyak dilakukan sejak beberapa tahun terakhir. Dalam sebuah penelitian tentang sistem peramalan penjualan menggunakan metode exponential smoothing, Sistem dapat meramal jumlah barang yang akan terjual pada periode 1 bulan ke depan, namun tidak diketahui akurasi peramalan maupun persentase kesalahan seperti MAD dan MSE yang terdapat pada peramalan tersebut [2]. Dalam penelitiannya di tahun 2013, Sandino dan Sunneng Berutu [3] melakukan peramalan penjualan dengan metode fuzzy time series Ruey Chyn Tsaur. Penelitian tersebut mampu meramalkan penjualan 1 bulan ke depan dengan tingkat akurasi yang cukup baik. Terdapat penelitian lainnya yang menerapkan metode exponential smoothing untuk meramalkan penggunaan waktu telepon di PT. Telkomsel Divre 3 Surabaya [4]. Penelitian tersebut membandingkan metode exponential smoothing, double exponential smoothing, dan weighted moving average. Hasil peramalan menggunakan double exponential smoothing menunjukkan hasil yang cukup baik. Parameter Alpha dan Beta ditentukan menggunakan metode ordinary least square sehingga mendapatkan nilai evaluasi di bawah $10 \%$. Peramalan menggunakan double exponential smoothing terbukti memberikan hasil peramalan yang lebih baik dibandingkan dengan metode exponential smoothing dan weighted moving average dengan selisih error sebesar 0.29\% dan selisih RMSE 74.15. Pada tahun 2012, Radiant Imbar Victor dan Yon Andreas [5] melakukan penelitian peramalan stok barang menggunakan double exponential smoothing. Dengan aplikasi tersebut sebuah proses pembelian barang serta pencarian data transaksi jadi lebih praktis.

\section{LANDASAN TEORI}

\section{Peramalan (Forecasting)}

Pada dasarnya peramalan adalah taksiran. Dengan menggunakan metode tertentu, peramalan bukan hanya sekedar taksiran, meskipun masih terdapat kesalahan. Mengapa membuat peramalan apabila peramalan bukan merupakan hal yang eksak?
Menurut Bambang Soepeno [1], peramalan diperlukan karena semua keputusan di masa yang akan datang didasarkan pada permalan saat ini. Kunci bagi keberhasilan perkembangan organisasi adalah kemampuan organisasi tersebut dalam menyesuaikan strateginya di lingkungan yang berubah dengan cepat.

Dalam Kamus Besar Bahasa Indonesia (KBBI), pengertian peramalan adalah kegiatan untuk menduga hal yang akan terjadi. Terdapat beberapa definisi lain tentang peramalan antara lain:

- Peramalan adalah kegiatan memperkirakan tingkat permintaan produk yang diharapkan untuk suatu produk atau beberapa produk dalam periode waktu tertentu di masa yang akan datang [6].

- Peramalan adalah proses untuk memperkirakan berapa kebutuhan di masa mendatang yang meliputi kebutuhan dalam ukuran kuantitas, kualitas, waktu, dan lokasi yang dibutuhkan dalam rangka memenuhi permintaan barang atau jasa [1]. Peramalan merupakan bagian internal dari kegiatan pengambilan keputusan manajemen [7].

- Peramalan adalah prediksi apa yang akan terjadi pada masa yang akan datang. Sedangkan rencana merupakan penentuan apa yang akan dilakukan pada waktu yang akan datang. Dengan sendirinya, terjadi perbedaan antara peramalan dengan rencana [8].

- Peramalan adalah prediksi, rencana, atau estimasi kejadian masa depan yang tidak pasti.

Peramalan tidak selalu dibutuhkan dalam kondisi pasar dengan perubahan permintaan relatif kecil (kondisi pasar stabil), namun peramalan akan sangat dibutuhkan bila kondisi keadaan pasar bersifat kompleks dan dinamis. Dalam kondisi pasar bebas, permintaan pasar lebih banyak bersifat kompleks dan dinamis karena permintaan tersebut akan tergantung dari keadaan sosial, ekonomi, politik, aspek teknologi, produk pesaing, dan produk substitusi. Oleh sebab itu, peramalan yang akurat merupakan informasi yang sangat dibutuhkan dalam pengambilan keputusan manajemen [1].

Terdapat beberapa langkah yang harus diperhatikan dalam membuat suatu ramalan untuk menjamin efektifitas dan efisiensi dari aplikasi peramalan, yaitu:

- Menentukan tujuan peramalan, berfungsi untuk menentukan estimasi yang diinginkan sesuai dengan kebutuhan-kebutuhan informasi para manajer.

- Memilih objek yang akan diramalkan.

- Menentukan horizon waktu peramalan, misal: jangka pendek, jangka menengah, jangka panjang.

- Memilih metode peramalan.

- Memperoleh data yang dibutuhkan untuk melakukan peramalan. 
- Pengembangan model, merupakan suatu kerangka analisa yang bila diberikan data akan menghasilkan estimasi penjualan di waktu yang akan datang.

- Pengujian model atau validasi metode peramalan, model diuji untuk menentukan tingkat akurasi, validasi, dan realibilitas yang diharapkan.

- Penerapan model dan implementasi hasil peramalan, data historis dimasukkan ke dalam model untuk menghasilkan suatu ramalan.

- Verifikasi, revisi dan evaluasi, ramalan yang telah dibuat harus diperbaiki dan ditinjau senantiasa. Perbaikan mungkin diperlukan karena terdapat perubahan-perubahan dalam perusahaan atau lingkungan.

Dalam peramalan tidak jarang terjadi kesalahan, misalnya peramalan penjualan sering tidak sama dengan nilai eksak yang diperkirakan. Kelebihan atau kekurangan peramalan terhadap kebutuhan dapat dijadikan kapasitas tambahan atau penjadwalan permintaan. Tetapi kelebihan atau kekurangan yang besar dapat merusak operasi. Menurut John E. Biegel [6] ada tiga cara untuk mengakomodasi perkiraan yaitu:

- Coba kurangi kesalahan dengan menggunakan metode peramalan yang lebih baik dan cocok.

- Buat fleksibilitas pada operasi.

- Memperkecil atau mempersempit waktu peramalan.

\section{Jenis-Jenis Pola Data}

Sebelum memilih metode time series, langkah penting yang harus dilakukan adalah mempertimbangkan jenis pola data, sehingga metode yang paling tepat dengan pola tersebut dapat diuji. Pola data dapat dibedakan menjadi empat jenis yaitu [7]:

\section{- Pola Horizontal (Horizontal Data Pattern)}

Pola data ini terjadi ketika data berfluktuasi di sekitar nilai rata-rata yang konstan. Suatu produk yang penjualannya tidak meningkat atau menurun dalam kurun waktu tertentu, termasuk pola data jenis ini.

- Pola Trend (Trend Data Pattern)

Pola data ini terjadi ketika terdapat kenaikan atau penurunan jangka panjang dalam data. Contohnya penjualan perusahaan, GNP (Gross National Product), dan berbagai indikator bisnis atau ekonomi lainnya.

- Pola Musiman (Seasional Data Pattern)

Pola data ini terjadi ketika suatu deret dipengaruhi oleh faktor musiman. Misalnya pada hari tertentu pada minggu tertentu, bulan tertentu, perempat tahun tertentu. Penjualan produk seperti payung, es krim, dan bahan bakar pemanas ruangan menunjukkan jenis pola ini.

\section{- Pola Siklis (Cyclied Data Pattern)}

Pola data ini terjadi ketika data dipengaruhi oleh fluktuasi ekonomi jangka panjang seperti berhubungan dengan siklus bisnis. Contohnya: penjualan mobil, baja.

\section{Peramalan Penjualan (Sales Forecasting)}

Peramalan penjualan mengacu pada prediksi penjualan mendatang berdasar data histori. Berkaitan dengan kompetensi dan globalisasi, peramalan penjualan memainkan peran penting pada sistem pengambilan keputusan pada perusahaan komersil [9]. Efektifitas ramalan penjualan akan menolong pengambil keputusan menghitung kemudian memperkirakan alokasi biaya dan produksi serta meningkatkan harga jual. Metode peramalan yang tepat dapat menolong pengecer mengurangi biaya kelebihan atau kekurangan stok.

\section{Pemulusan Eksponensial Tunggal (Single Exponen- tial Smoothing)}

Menurut Bambang Soepeno dalam bukunya yang berjudul Modul Peramalan Penjualan [1], Single Exponential Smoothing merupakan suatu metode yang bekerja hampir serupa dengan alat thermostat. Bila selisih antara data aktual dengan data peramalan bernilai positif, maka metode ini akan secara otomatis meningkatkan hasil ramalan berikutnya dan sebaliknya, bila selisih tersebut negatif, maka metode ini akan menurunkan nilai ramalan. Proses penyesuaian ini berlangsung terus menerus kecuali selisih data telah mencapai nol. Kenyataan inilah yang mendorong peramal lebih suka menggunakan metode eksponensial. Peramalan menggunakan model pemulusan eksponensial dilakukan berdasarkan formula sebagai berikut:

$F_{t}=F_{t-1}+\alpha\left(A_{t-1}-F_{t-1}\right)$

dimana:

$\mathrm{Ft}=$ nilai ramalan untuk periode ke- $\mathrm{t}$

Ft-1 = nilai ramalan untuk satu periode waktu yang lalu, $\mathrm{t}-1$

At-1 = nilai aktual untuk satu periode waktu yang lalu, $\mathrm{t}-1$

$\alpha=$ konstanta pemulusan

\section{Pemulusan Eskponensial Ganda (Double Exponential Smoothing)}

Double Exponential Smoothing merupakan metode yang akan digunakan dalam penelitian ini. Dasar pemikiran dari metode ini adalah bahwa nilai pemulusan akan terdapat pada waktu sebelum data sebenarnya apabila pada data tersebut terdapat 
komponen trend. Oleh karena itu untuk nilai pemulusan tunggal, perlu ditambahkan dengan nilai pemulusan ganda untuk menyesuaikan trend. Metode yang dapat digunakan untuk memprediksi trend linear adalah metode dua parameter dari Holt. Pada metode Holt, nilai trend tidak dimuluskan dengan pemulusan ganda secara langsung, namun pemulusan trend dilakukan dengan menggunakan parameter berbeda dengan parameter yang digunakan untuk pemulusan data asli. Berikut persamaan pemulusan eksponensial ganda:

$$
\begin{aligned}
& S_{t}=\alpha X_{t}+(1-\alpha)\left(S_{t-1}+B_{t-1}\right) \\
& B_{t}=\beta\left(S_{t}-S_{t-1}\right)+(1-\beta) B_{t-1} \\
& f_{t}=S_{t-1}+B_{t-1} \cdot m
\end{aligned}
$$

dimana:

St $=$ Nilai pemulusan tunggal

$\mathrm{Xt}=$ Nilai aktual pada periode ke-t

$\mathrm{Bt}=$ Pemulusan trend

$\mathrm{Ft}=$ Nilai ramalan pada periode ke- $\mathrm{t}$

$\mathrm{m}=$ Periode masa mendatang

$\alpha, \beta=$ Konstanta pemulusan dengan nilai antara 0 dan 1

\section{Mean Absolute Percentage Error (MAPE)}

MAPE adalah cara yang digunakan untuk menghitung persentase kesalahan peramalan pada penelitian ini. MAPE merupakan rata-rata persentase kesalahan absolut yang didapat dengan membagi persentase kesalahan tiap periode peramalan, dengan jumlah periode peramalan yang ada. Persentase kesalahan tiap periode peramalan disebut juga PE (Percentage Error). PE didapat dari nilai absolut data asli pada periode tertentu yang dikurangi dengan hasil peramalan pada periode yang sama, kemudian dibagi dengan data asli dan dikali $100 \%$. Secara matematis MAPE dinyatakan sebagai berikut:

$M A P E=\left(\frac{100}{n}\right) \cdot \sum_{t=1}^{n}\left|\frac{x_{t}-f_{t}}{x_{t}}\right|$

dimana:

$\mathrm{n}$ = Jumlah data yang memiliki nilai aktual dan ramalan

$\mathrm{t}=$ periode waktu ke- $\mathrm{t}$

$\mathrm{Xt}=$ Nilai aktual pada periode ke- $\mathrm{t}$

$\mathrm{ft}=$ Nilai ramalan pada periode ke-t

\section{METODOLOGI PENELITIAN}

Metodologi penelitian yang diterapkan dalam pelaksanaan penelitian dapat dijabarkan sebagai berikut:

\section{Studi pustaka}

Studi pustaka dilakukan melalui pembelajaran terhadap jurnal, artikel, laporan penelitian, mau- pun sumber lain, yang tersedia secara online atau offline serta berhubungan dengan penelitian yang dilakukan, terutama mengenai metode peramalan dan Double Exponential Smoothing.

2. Perancangan aplikasi

Pada tahap ini terdapat beberapa hal yang perlu dilakukan, mulai dari merancang tampilan antarmuka dan aliran data, mendokumentasikan rancangan tersebut ke dalam bentuk diagram alir, memilih bahasa pemrograman serta framework yang menyediakan fungsionalitas yang dibutuhkan, hingga akhirnya aplikasi dapat mulai dibangun.

3. Pengumpulan data

Sampel data didapat dengan memberikan proposal kepada PT. Sanpak Unggul yang berisi request terhadap sampel data asli penjualan 10 jenis produk dari Januari 2012 sampai Maret 2015.

4. Pembangunan dan penerapan metode peramalan Pembangunan aplikasi dilakukan sesuai dengan rancangan yang telah disiapkan dalam tahap sebelumnya. Penerapan Double Exponential Smoothing sebagai metode peramalan yang digunakan dalam penelitian ini juga dilakukan. Untuk keperluan pengujian, maka sampel data yang berhasil dikumpulkan akan diterapkan dalam aplikasi dan dianalisis pada tahap selanjutnya

5. Analisis data

Sampel data yang didapat dianalisis untuk mendapatkan hasil peramalan dan akurasi metode pada aplikasi yang dibangun, juga untuk mengetes fiturfitur lain seperti tambah, edit, dan hapus data.

6. Testing dan debug aplikasi

Beberapa pengujian dilakukan terhadap fungsionalitas yang dibuat dalam aplikasi untuk memastikan agar fungsi-fungsi tersebut berjalan sebagaimana harusnya dan terintegrasi dengan sistem, sebelum akhirnya diimplementasikan di internal perusahaan.

7. Dokumentasi dan publikasi

Hasil penelitian didokumentasikan dalam bentuk suatu laporan ilmiah Tugas Akhir dan akan dipublikasikan melalui jurnal ilmiah berkala tingkat nasional.

\section{PERANCANGAN SISTEM}

Dalam tahapan perancangan fungsional aplikasi, akan dibuat beberapa diagram seperti Data Flow Diagram (DFD), Flowchart, dan rancangan antarmuka aplikasi.

- Data Flow Diagram

Pada pembuatan aplikasi ini, Data Flow Diagram (DFD) dirancang untuk menggambarkan aliran data yang terjadi pada aplikasi tersebut sehingga 
dapat memudahkan dalam membangun sistem ini. Berikut Data Flow Diagram (DFD) pada aplikasi ini.

\section{- DFD Level 0}

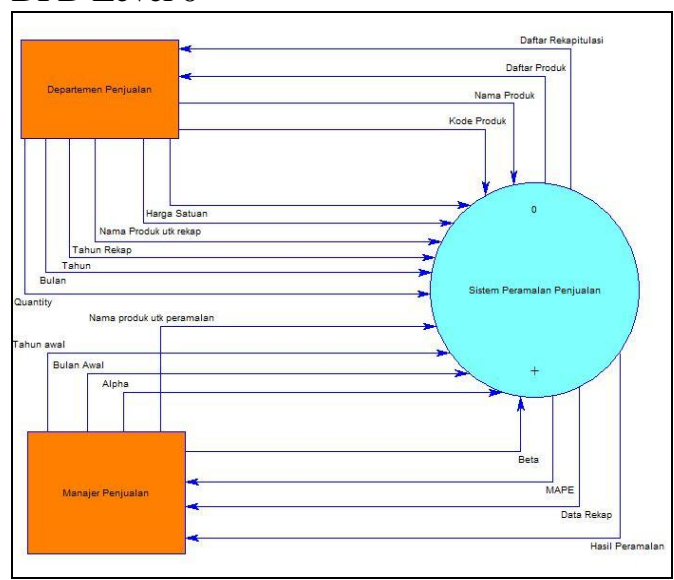

Gambar 1. DFD level 0

\section{- DFD Level 1}

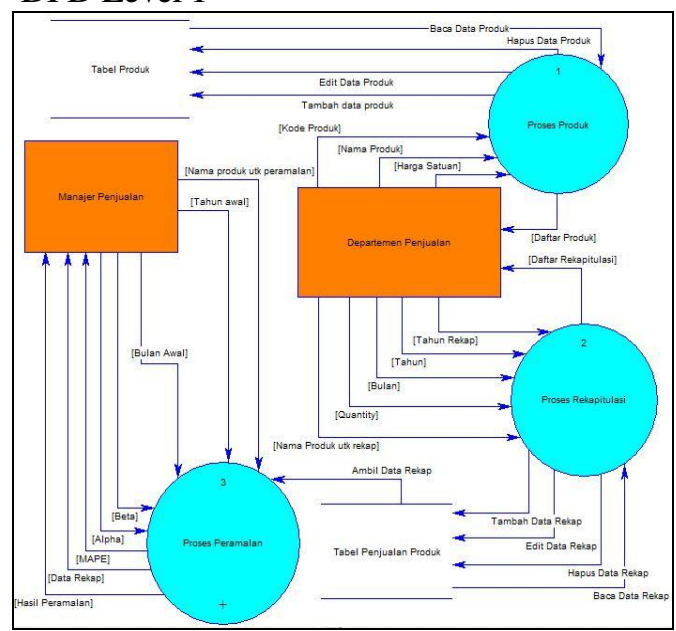

Gambar 2. DFD level 1

- DFD Level 2

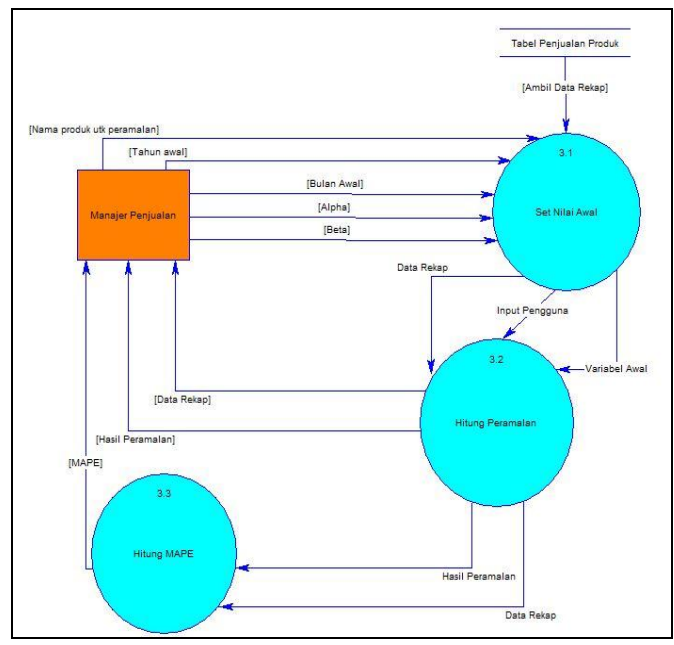

Gambar 3. DFD Level 2
- Flowchart

Flowchart merupakan suatu bagan yang menggambarkan urutan proses secara detail dan hubungan antara suatu proses dengan proses yang lain dalam suatu program, dimana pada flowchart juga terdapat simbol-simbol yang memiliki fungsinya masing-masing. Simbol-simbol yang terdapat pada flowchart, yaitu terminator, flow line, proses, decision, preparation, predefined process, dan lain-lain.

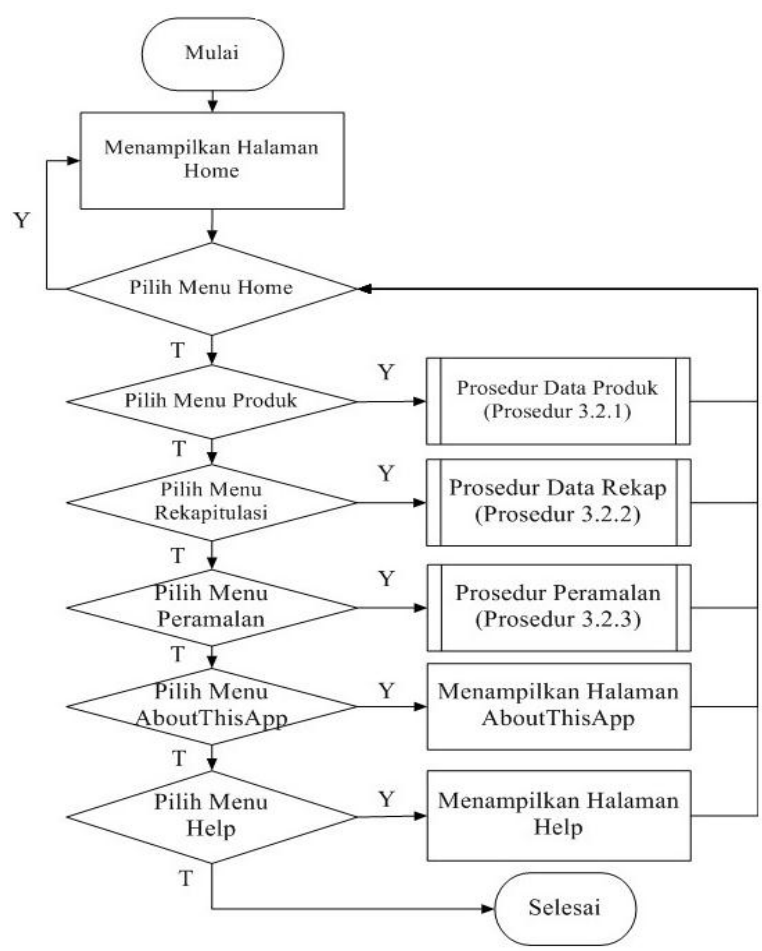

Gambar 4. Flowchart Utama Aplikasi

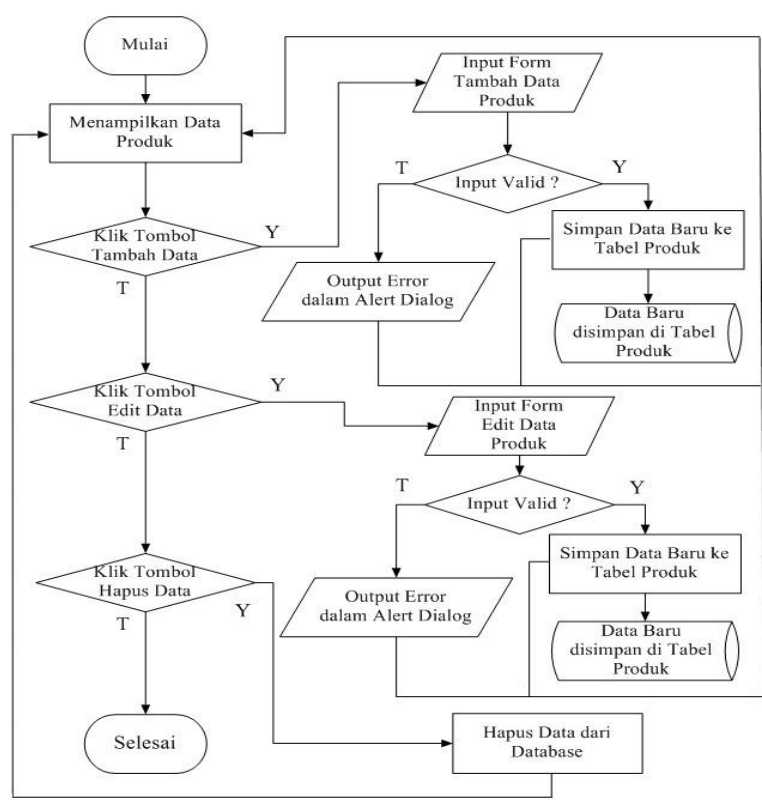

Gambar 5. Flowchart Produk 


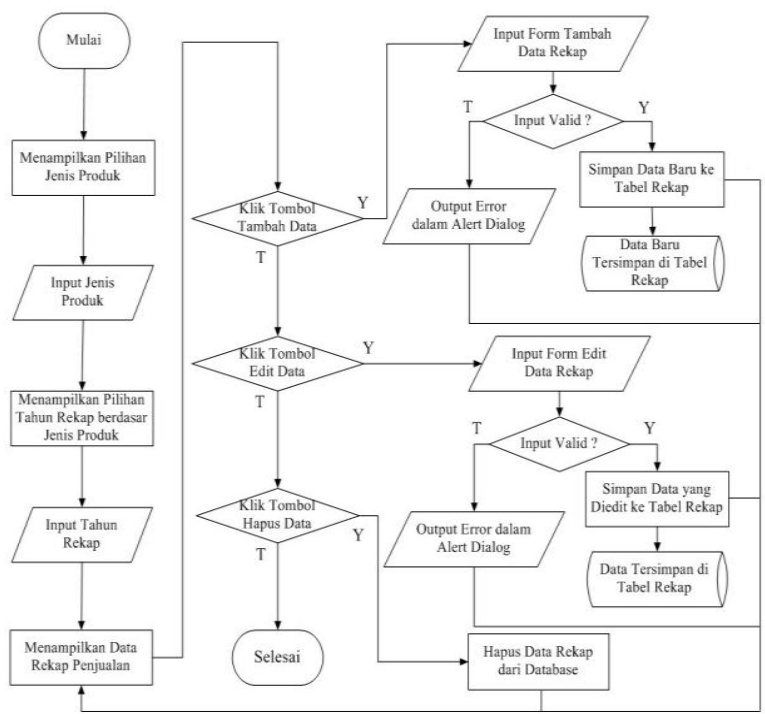

Gambar 6. Flowchart Rekap

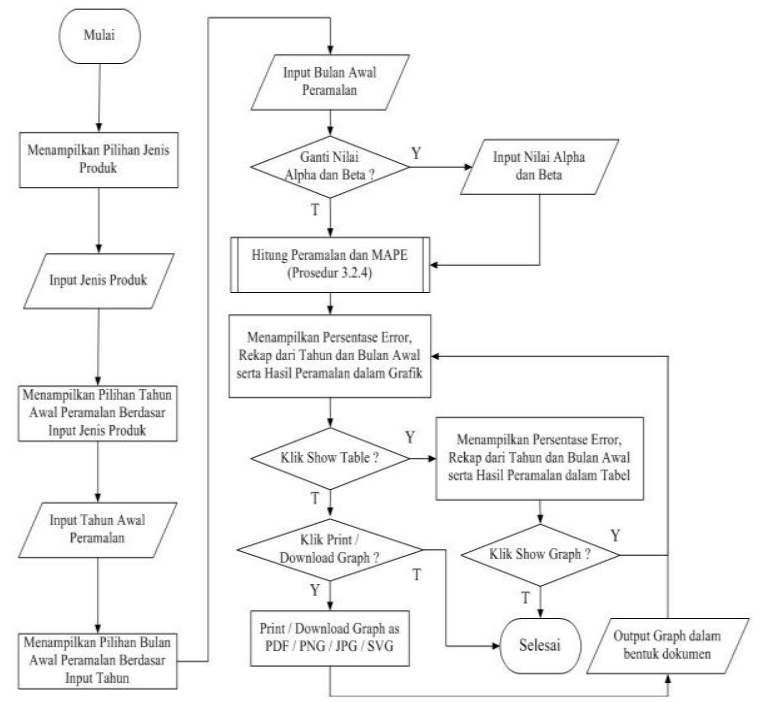

Gambar 7. Flowchart Peramalan

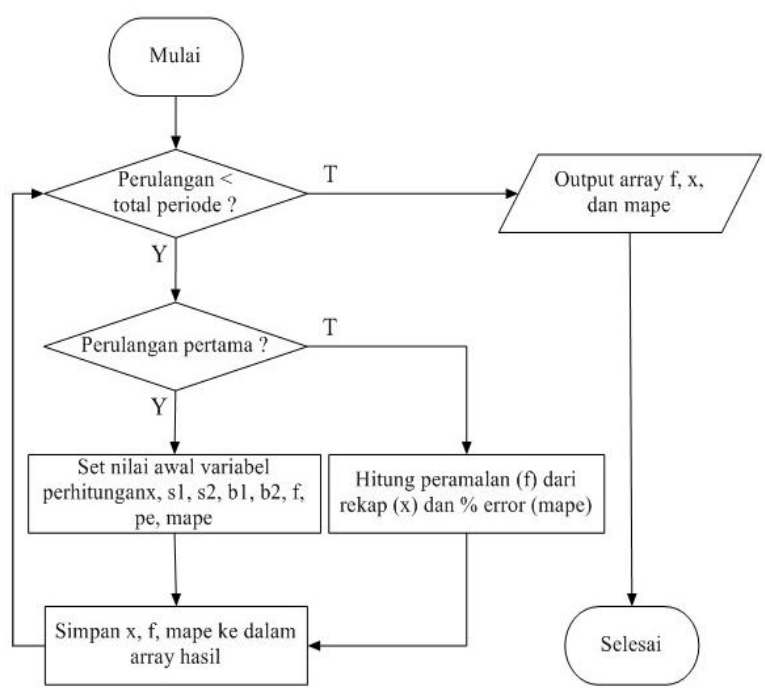

Gambar 8. Flowchart Double Exponential Smoothing
- Rancangan antarmuka aplikasi

Rancangan antarmuka aplikasi dibuat semenarik mungkin dan mudah untuk digunakan oleh orang awam.

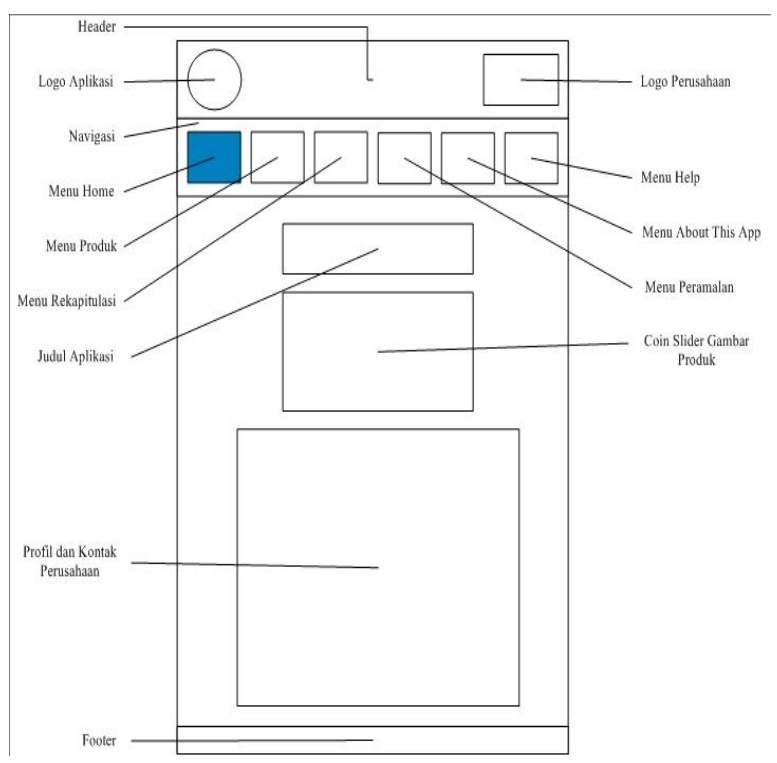

Gambar 9. Rancangan Antarmuka Tampilan Aplikasi

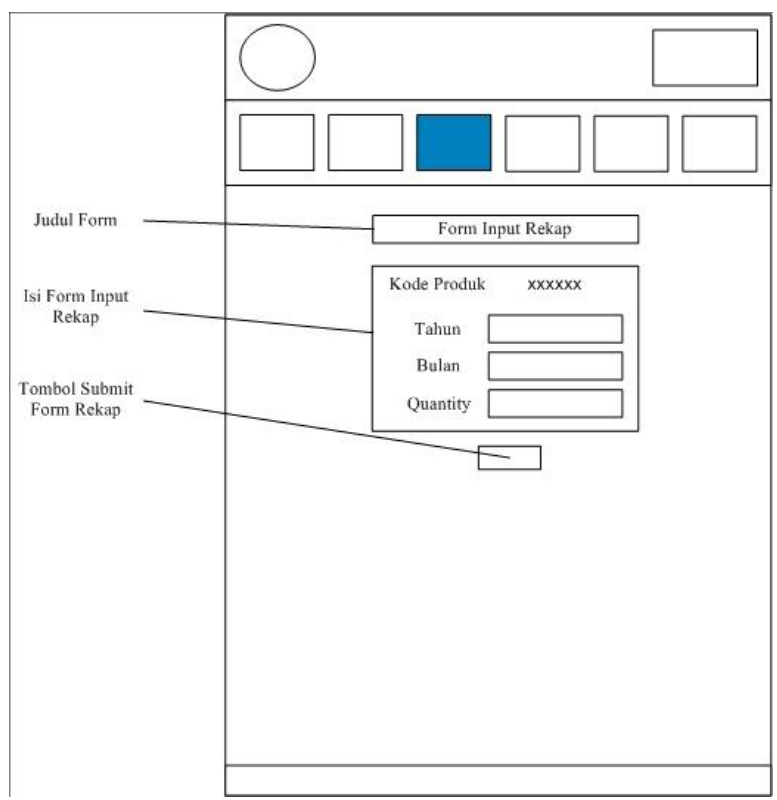

Gambar 10. Rancangan Antarmuka Tampilan Form Aplikasi

\section{IMPLEMENTASI DAN UJI COBA}

\section{Hasil Implementasi}

Gambar 11 memperlihatkan tampilan utama aplikasi yang telah dibangun. Pada halaman ini, ditampilkan beberapa produk yang dijual dan profile singkat perusahaan. 


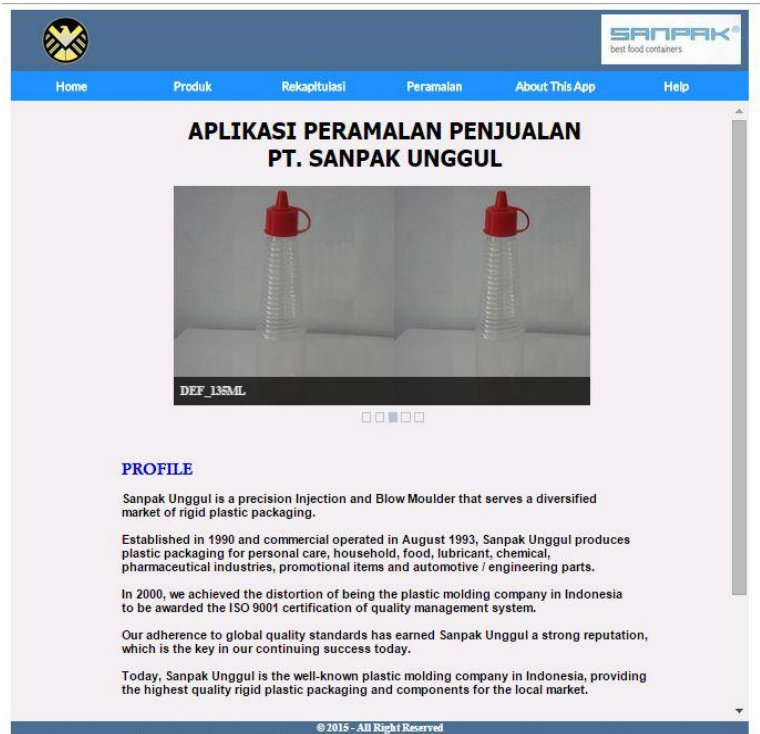

Gambar 11. Tampilan Halaman Home

Gambar 12 memperlihatkan tampilan halaman produk yang tersimpan dalam database, sementara Gambar 13 merupakan tampilan input data produk baru yang dapat digunakan oleh user untuk menambahkan data produk dalam database.

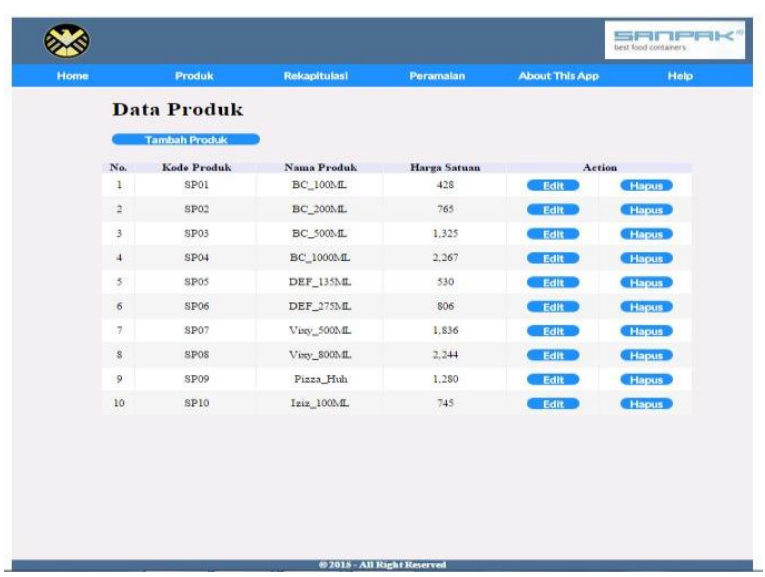

Gambar 12. Tampilan Halaman Produk

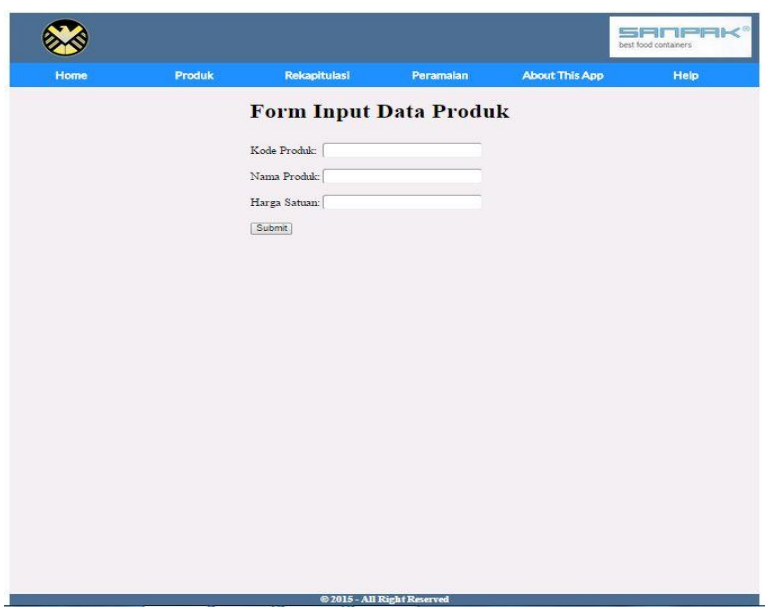

Gambar 13. Tampilan Halaman Tambah Produk
Hasil prediksi penjualan ditampilkan dalam halaman peramalan sebagaimana yang diperlihatkan pada Gambar 14, sementara Gambar 15 memperlihatkan halaman bantuan yang dapat dimanfaatkan user untuk mempelajari fungsionalitas sistem yang dibangun.

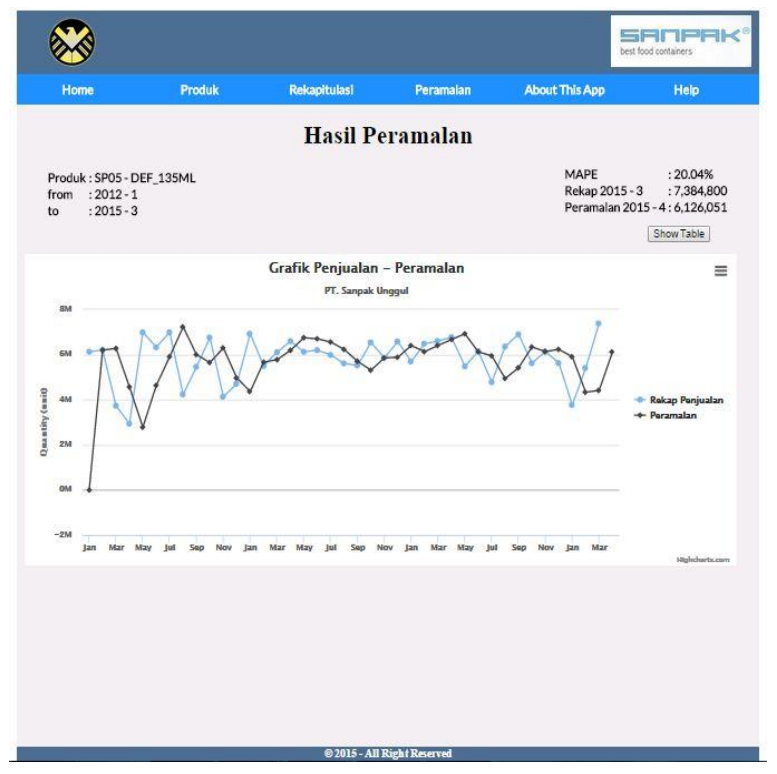

Gambar 14. Tampilan Halaman Peramalan (grafik)

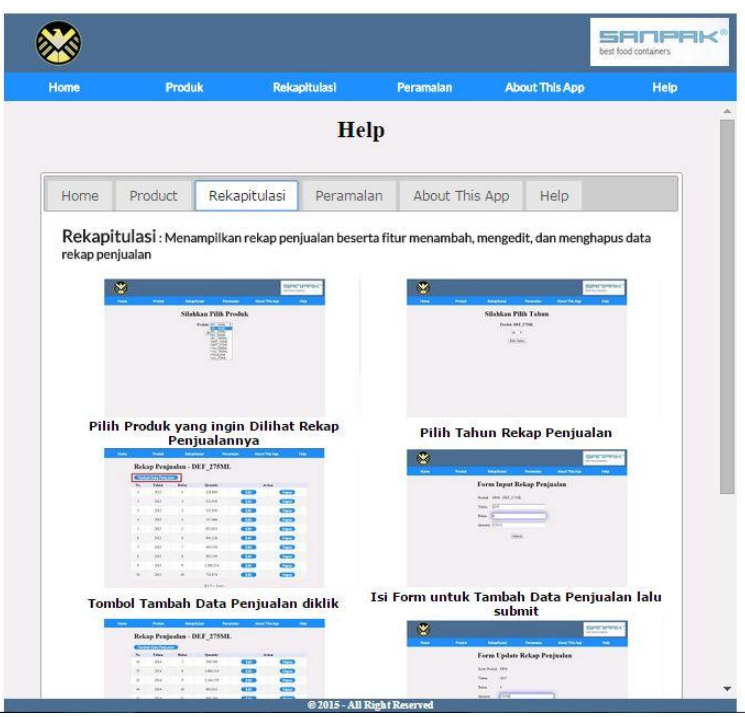

Gambar 15. Tampilan Halaman Help

\section{Uji Coba Akurasi}

Untuk mengukur tingkat akurasi aplikasi ini, digunakan sebuah standar persentase kesalahan peramalan yaitu MAPE. MAPE didapat dengan menjumlahkan seluruh pe yang dibagi dengan jumlah pe. Nilai MAPE yang didapat dari produk ini adalah $20.04 \%$. Perbandingan hasil ramal tiap produk dengan data rekapitulasi kuantitas penjualan yang digambarkan dalam bentuk grafik, dapat dilihat pada lampiran. 
Tabel di bawah ini menunjukkan hasil MAPE 10 jenis produk yang digunakan pada penelitian ini dari periode tahun 2012 bulan Januari hingga tahun 2015 bulan Maret. Rata-rata MAPE dari algoritma double exponential smoothing pada 10 jenis produk tersebut adalah $28,383 \%$.

Tabel 1. Tabel MAPE Seluruh Produk

\begin{tabular}{lc}
\hline Produk & MAPE \\
\hline BC_100ML & $28,97 \%$ \\
BC_200ML & $27,23 \%$ \\
BC_500ML & $25,60 \%$ \\
BC_1000ML & $29,25 \%$ \\
DEF_135ML & $20,04 \%$ \\
DEF_275ML & $35,38 \%$ \\
Vixy_800ML & $20,95 \%$ \\
Pizza_Huh & $38,67 \%$ \\
Izzy_100ML & $35,87 \%$ \\
\hline Rata-rata & $28,383 \%$ \\
\hline
\end{tabular}

Rata-rata kesalahan tersebut digambarkan dalam grafik batang pada gambar di bawah ini.

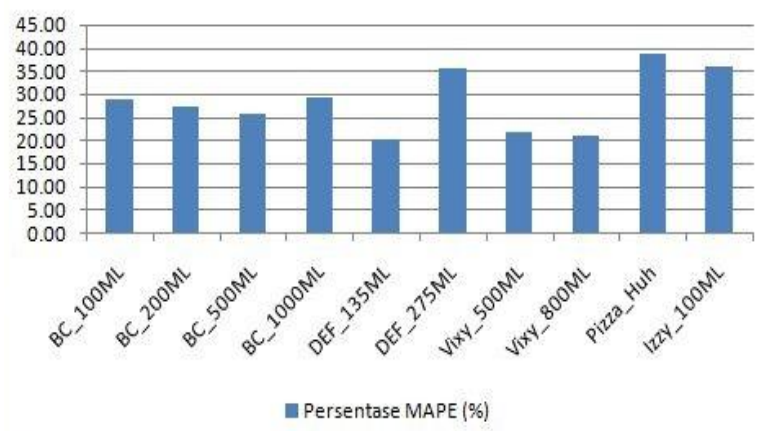

Gambar 16. Diagram Barang MAPE Seluruh Produk

\section{KESIMPULAN}

Aplikasi web untuk melakukan peramalan penjualan berdasarkan data penjualan sebelumnya telah berhasil dibuat. Beberapa fitur tambahan yang dibutuhkan pengguna juga sudah ditambahkan. Berdasarkan jawaban yang diisikan pada kuisioner, dapat disimpulkan bahwa pengguna sudah cukup puas dengan aplikasi ini. Dari hasil analisis penelitian, didapat persentase kesalahan MAPE yang merupakan ukuran akurasi peramalan yang menggunakan metode double exponential smoothing ini. Rata-rata persentase kesalahan perhitungan dari seluruh produk adalah 28,383\%. Peramalan pada produk DEF_135ML memiliki persentase kesalahan terkecil yaitu 20,04\% Sedangkan peramalan pada produk Pizaa_Huh memiliki persentase kesalahan terbesar sebesar 38,67\%.

\section{DAFTAR PUSTAKA}

[1]. Soepeno, Bambang, 2010. Modul Peramalan Penjualan. Politeknik Negeri Malang, Malang.

[2]. Setya, Krisna Wardana, Supriyanto, Antok, dan Arifin, M., 2011. Sistem Informasi Estimasi Penjualan Dengan Menggunakan Metode Exponensial Smoothing (Studi Kasus: PT. Sumber Bening Lestari). Stikom, Surabaya.

[3]. Sandino, Sunneng Berutu, 2013. Tesis: Peramalan Penjualan Dengan Metode Fuzzy Time Series Ruey Chyn Tsaur. Universitas Diponegoro, Semarang.

[4]. Raharja, Alda, Angraeni, Wiwik, dan Aulia, Retno Vinarti, 2010. Penerapan Metode Exponential Smoothing Untuk Peramalan Penggunaan Waktu Telepon di PT. Telkomsel Divre3 Surabaya. Institut Teknologi Sepuluh November. Surabaya.

[5]. Victor, Radiant Imbar dan Andreas, Yon, 2012. Aplikasi Peramalan Stok Barang Menggunakan Metode Double Exponential Smoothing. Jurnal Sistem Informasi, Vol 7, No 2, September 2012: 123-141, Bandung.

[6]. Biegel, John E, 1999. Pengendalian Produksi Suatu Pendekatan Kuantitatif. Akademika Presindo, Jakarta

[7]. Makridakis, Spyross, Steven C., Whellwright, Victore Mcgee, Untung Susandriyanto, Abdul Basith, 1988. Metoda dan Aplikasi Peramalan, Jilid Satu Edisi Kedua. Erlangga, Jakarta

[8]. Subagyo, Pangestu, 1986. Forecasting Konsep dan Aplikasi, BPPE UGM, Yogyakarta

[9]. Kuo R. J, Xue K. C, 1998. A Decision Support System for sales Forecasting through Fuzzy Neural Networks and Asymmetric Fuzzy Weights. Decision Support Systems 24 102-126. 